\title{
ANALISIS DAYA DUKUNG PILE SLAB JEMBATAN LAYANG JALAN BUKIT RAWI KALIMANTAN TENGAH
}

\author{
Bagasianari Tarigan $^{1}$, Suradji Gandi ${ }^{2}$ dan Mohammad Ikhwan Yani ${ }^{3}$ \\ ${ }^{123}$ Program Studi Teknik Sipil, Fakultas Teknik, Universitas Palangka Raya \\ E-mail: bagastarigan30@gmail.com ${ }^{1}$, suradjigandi_ir@jts.upr.ac.id ${ }^{2}$, dan \\ m.ikhwanyani@eng.upr.ac.id ${ }^{3} / H P .+6282151650640^{1}$
}

\begin{abstract}
ABSTRAK
Pada saat musim penghujan, lokasi jalan Bukit Rawi, Kalimantan Tengah sering mengalami kebanjiran dan mengakibatkan kemacetan yang sangat panjang. Sehingga untuk mengatasi masalah tersebut maka dibangun jembatan layang dengan menggunakan struktur Slab on Pile. Pada saat pembangunan ditemukan beberapa kendala salah satunya adalah lokasi tersebut memiliki jenis tanah gambut yang memiliki daya dukung sangat rendah. Penelitian ini bertujuan untuk mengetahui kapasitas daya dukung pile slab yang terjadi pada jembatan layang di jalan Bukit Rawi berdasarkan data SPT dan CPT, dan mengetahui berapa besar penurunan yang terjadi pada pile slab di jalan Bukit Rawi. Data penelitian diperoleh dari data sekunder yang didapatkan dari P2JN (Perencanaan dan Pengawasan Jalan Nasional) Provinsi Kalimantan Tengah. Perhitungan pembebanan pada struktur atas dilakukan dengan menggunakan SAP2000. Berdasarkan hasil perhitungan data SPT, besar daya dukung tiang pancang tunggal dengan metode Meyerhof sebesar 91,01 ton (aman), metode L Decourt sebesar 40,143 ton (tidak aman). Berdasarkan hasil perhitungan data CPT, besar daya dukung tiang pancang tunggal dengan metode Aoki dan De Alencar sebesar 92,17 ton (aman), metode Langsung sebesar 216,971 ton (aman), metode Philipponnat sebesar 89,344 ton (aman). Penurunan yang terjadi pada pile slab adalah sebesar 7,3 mm.
\end{abstract}

Kata kunci: daya dukung, pile slab, jembatan layang, CPT, SPT.

\section{ABSTRACT}

During the rainy season, the location of Bukit Rawi street, Central Kalimantan is often flooded and causes a very long traffic jam. So to overcome this problem, a flyover was built using the Slab on Pile structure. At the time of construction, several obstacles were found, one of which was that the location had a type of peat soil which had a very low carrying capacity. This study aims to determine the carrying capacity of the pile slab that occurs on the flyover on the Bukit Rawi road based on SPT and CPT data, and to find out how much reduction occurs in the pile slab on the Bukit Rawi road. The research data were obtained from secondary data obtained from P2JN (National Road Planning and Supervision), Central Kalimantan Province. The load calculation on the upper structure is carried out using SAP2000. Based on the results of SPT data calculations, the carrying capacity of a single pile using the Meyerhof method is 91.01 tons (safe), the L Decourt method is 40.143 tons (unsafe). Based on the calculation of CPT data, the carrying capacity of a single pile using the Aoki and De Alencar method is 92.17 tons (safe), the Direct method is 216.971 tons (safe), the Philipponnat method is 89.344 tons (safe). The decrease that occurred in the pile slab was $7.3 \mathrm{~mm}$.

Key word: carrying capacity, pile slab, flyover, CPT, SPT. 


\section{PENDAHULUAN}

Kalimantan Tengah merupakan salah satu Provinsi Indonesia yang ber ibu kota di Palangka Raya semakin berbenah diri dalam pembangunan di berbagai sektor, terkhususnya di sektor pembangunan jembatan layang yang dilaksanakan di jalan bukit rawi. Total panjang jembatan layang tersebut sepanjang $3,15 \mathrm{~km}$ terbagi atas 2 tahap yakni tahap I sepanjang $800 \mathrm{~m}$ dan tahap II sepanjang $2350 \mathrm{~m}$. Pembangunan jembatan layang Bukit Rawi ini awalnya direncanakan akan selesai tahap I pada akhir tahun 2019 akan tetapi pada saat pembangunan ditemukan beberapa kendala salah satunya yaitu ditemukannya tanah rawa dan gambut pada lokasi dimana jembatan layang akan dibangun, yang mana mengakibatkan proses konstruksi jembatan layang ini terhambat karena tanah rawa dan gambut tidak dapat memikul beban atau dengan kata lain tanah yang memiliki daya dukung yang sangat rendah. Telah dilakukan beberapa penelitian dengan tujuan untuk mendapatkan solusi dalam mengatasi masalah tanah dasar rawa yang berindikasikan tidak stabil, dalam hal ini penulis mengambil wacana penggunaan konstruksi Pile slab untuk perencanaan infrastruktur jembatan layang Bukit Rawi.

\section{Tujuan Penelitian}

Tujuan dari penelitian ini adalah untuk mengetahui berapa besar daya dukung pile slab yang terjadi pada jembatan layang di jalan Bukit Rawi berdasarkan data SPT dengan menggunakan metode Meyerhof dan L. Decourt dan berdasarkan data CPT menggunakan metode Aoki dan De Alencar, Langsung, dan Philipponnat. dan mengetahui berapa besar penurunan yang terjadi pada pile slab di jalan Bukit Rawi.

\section{METODE PENELITIAN}

\section{Lokasi Penelitian}

Penelitian ini dilakukan pada proyek pembangunan pile slab Bukit Rawi, Kecamatan Kahayan Tengah, Kabupaten Pulang Pisau, Provinsi Kalimantan Tengah, Indonesia.

\section{Analisis dan Perhitungan Struktur}

Tahapan analisis perhitungan beserta acuannya dalam perencanaan struktur slab on pile adalah sebagai berikut:

1. Analisa keadaan serta kondisi tanah.

2. Menghitung berat sendiri.

3. Menghitung beban mati tambahan.

4. Menghitung beban lalu lintas.

5. Menghitung beban " $\mathrm{D}$ ".

6. Menghitung beban truk " $T$ ".

7. Menghitung beban angin.

8. Menghitung beban gempa.

9. Penentuan beban - beban yang bekerja pada struktur baik beban gravitasi / vertikal maupun beban gempa / lateral.

\section{Metode Pengumpulan Data}

Metode pengumpulan data dilakukan dengan cara: 
1. Metode literatur yaitu dengan mengumpulkan, mengidentifikasi, mengolah data tertulis dan metode kerja yang digunakan sebagai input proses perencanaan.

2. Metode observasi yaitu dengan melakukan pengamatan langsung ke lokasi untuk mengetahui kondisi sebenarnya dilapangan.

\section{Tahapan Penelitian}

Penelitian ini dilakukan dalam lima tahap, dimana dari tahap satu hingga tahap kelima memiliki hubungan yang saling mempengaruhi. Secara lengkap tahap-tahap kegiatan penelitian dijelaskan sebagai berikut :

\section{Tahap pertama}

Tahap pertama pada penelitian ini merupakan tahap pendahuluan. Proses-proses yang dilakukan pada tahap ini, yaitu:

1. Menyusun latar belakang penelitian

2. Menyusun rumusan masalah

3. Menyusun tujuan penelitian

4. Menyusun batasan masalah

5. Menyusun manfaat penelitian

\section{Tahap kedua}

Tahap kedua pada penelitian ini adalah tahap untuk melakukan review litelatur, yaitu:

1. Definisi fondasi

2. Macam-macam fondasi

3. Macam-macam tiang pancang beton

4. Daya dukung tanah

5. Perhitungan daya dukung fondasi berdasarkan SPT

6. Perhitungan daya dukung fondasi berdasarkan CPT

7. Pile slab

8. Pembebanan

\section{Tahap ketiga}

Tahap ketiga pada penelitian ini adalah tahapan pengolahan data dengan mengumpulkan data hasil pengujian SPT, guna menghitung daya dukung tanah fondasi dengan metode Meyerhof dan L. Decourt. Pengolahan data selanjutnya dengan memilah data perhitungan analisis struktur yang berupa beban mati dan beban hidup struktur bangunan jembatan layang. Jika memungkinkan akan ditinjau kembali menggunakan sofeware yang sesuai dengan kebutuhan data.

\section{Tahap keempat}

Pada tahap kempat ini adalah tahap untuk melakukan analisis perhitungan daya dukung tanah fondasi dengan metode Meyerhof dan metode L. Decourt. Untuk analisis pile slab mengunakan bantuan aplikasi SAP 2000 dan mengacu pada peraturan SNI-1725:2016 di mana daya dukung tanah fondasi beserta beban mati dan beban hidup di input dalam persamaannya. Output yang dihasilkan pada tahap keempat ini berupa daya dukung tanah fondasi yang tepat. 


\section{Tahap kelima}

Tahap kelima pada penelitian ini adalah pengambilan kesimpulan dan saran terhadap penelitian tugas akhir ini. Output yang dihasilkan berupa kesimpulan dan saran.

\section{Tahapan analisis data}

Langkah-langkah dan teknik analisa data yang digunakan dalam penelitian ini adalah:

1. Menganalisis gaya yang bekerja pada kelompok tiang.

2. Menghitung analisis beban atas dengan aplikasi SAP 2000.

3. Menghitung kapasitas daya dukung tiang pancang kelompok.

4. Menghitung kapasitas daya dukung berdasarkan data CPT dan SPT.

5. Menghitung penurunan tiang pancang.

\section{HASIL \& PEMBAHASAN}

\section{Beban Struktur Bangunan}

Hasil perhitungan analisa pembebanan dengan bantuan SAP2000, untuk beban maksimal bangunan yang bekerja pada fondasi $(\operatorname{Pmax})=68,468$ ton.

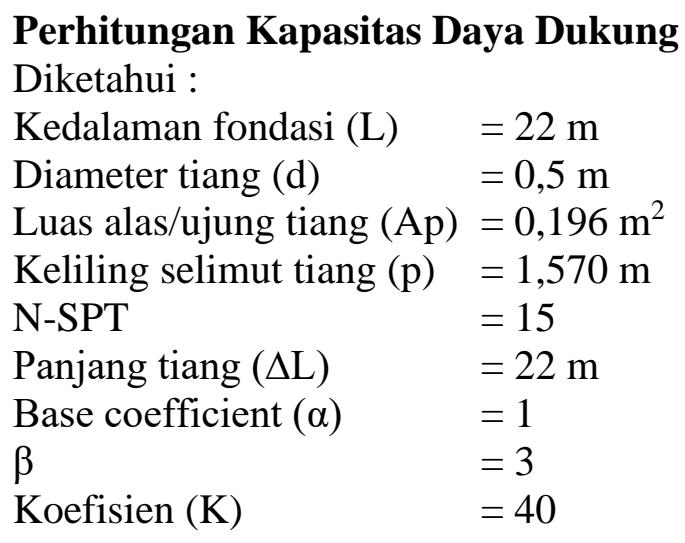

1. Metode Meyerhof

$$
\begin{aligned}
\text { Qp } & =40 \times \text { N-SPT } \times A p \\
& =40 \times 15 \times 0,196 \\
& =117,6 \text { ton } \\
\text { Qs } \quad & =0,3 \times \text { NSPT } \times \mathrm{p} \times \Delta \mathrm{L} \\
& =0.3 \times 15 \times 1,570 \times 22 \\
& =155,430 \text { ton } \\
\text { Qult } & =\mathrm{Qp}+\mathrm{Qs} \\
& =117,6+155,430 \\
& =273,030 \text { ton } \\
\mathrm{Q}_{\mathrm{a}} & =\frac{\mathrm{Q}_{\mathrm{u}}}{\mathrm{SF}}=\frac{273,03}{3}=91,01 \text { ton }
\end{aligned}
$$


Jadi, kapasitas daya dukung tiang tunggal dengan metode Meyerhof adalah sebesar 273,030 ton, dan kapasitas ijin tiang adalah sebesar 91,01 ton > 68,468 ton (aman).

2. Metode L. Decourt (1982)

$$
\begin{aligned}
\text { Qp } & =\alpha \cdot(\mathrm{Np} \cdot \mathrm{K}) \cdot \mathrm{Ap} \\
& =1 \times(15 \times 40 \times 0,196) \\
& =117,6 \text { ton } \\
\text { Qs } & =\beta \cdot(\mathrm{Ns} / 3+1) \cdot \text { As } \\
& =3 \times(15 / 3+1) \times 157,079 \\
& =2827,422 \mathrm{~kg} \\
& =2,827 \text { ton } \\
\text { Qu } & =\text { Qp }+ \text { Qs. } \\
& =117,6+2,827 \\
& =120,427 \text { ton } \\
\text { Qijin } & =\text { Qu/SF } \\
& =120,427 / 3 \\
& =40,143 \text { ton }
\end{aligned}
$$

Jadi, kapasitas daya dukung tiang tunggal dengan metode L. Decourt (1982) adalah sebesar 120,427 ton, dan kapasitas ijin tiang adalah sebesar 40,143 ton $<68,468$ ton (tidak aman).

\section{Perhitungan kapasitas daya dukung tiang tunggal berdasarkan CPT}

\section{Diketahui :}

Kedalaman fondasi (L) $\quad=2200 \mathrm{~cm}$

Dimensi tiang pancang $(\mathrm{d})=50 \mathrm{~cm}$

Keliling tiang pancang $(\mathrm{As})=157,079 \mathrm{~cm}$

Luas tiang pancang $(\mathrm{Ab})=1963,495 \mathrm{~cm}^{2}$

1. Metode Aoki dan De Alencar

a. Perhitungan kapasitas dukung ujung tiang $(\mathrm{Qb})$ :

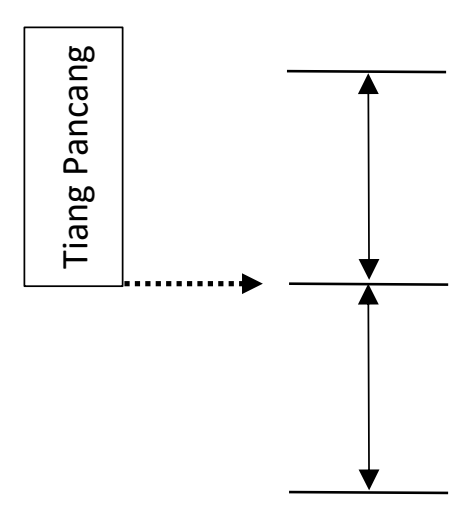

\begin{tabular}{|c|c|}
\hline $\begin{array}{c}\text { Kedalaman } \\
(\mathrm{m})\end{array}$ & $\begin{array}{c}\text { Perlawanan Konus } \\
\left(\mathrm{Kg} / \mathrm{cm}^{2}\right)\end{array}$ \\
\hline 21,20 & 159 \\
\hline 21,40 & 138 \\
\hline 21,60 & 141 \\
\hline 21,80 & 130 \\
\hline $\mathbf{2 2 , 0 0}$ & 127 \\
\hline 22,20 & 132 \\
\hline 22,40 & 132 \\
\hline 22,60 & 130 \\
\hline 22,80 & 143 \\
\hline
\end{tabular}

Gambar 1. Perkiraan Nilai qca (base) 
qca (base) merupakan perlawanan konus rata-rata 1,5 D diatas ujung tiang, dan 1,5 D dibawah ujung tiang.

$$
\begin{aligned}
\mathrm{qca}(\text { base }) & =1,5 \times \mathrm{D} \\
& =1,5 \times 0,5 \mathrm{~m} \\
& =0,75
\end{aligned}
$$

Jadi, perlawanan konus berada di kedalaman 0,80 $\mathrm{m}$ di atas ujung tiang dan $0,80 \mathrm{~m}$ di bawah ujung tiang.

1) Nilai $q_{c a}$ diambil rata-rata :

$$
\begin{aligned}
\mathrm{q}_{\mathrm{ca}} & =\frac{159+138+141+130+127+132+132+130+143}{9} \\
& =137 \mathrm{~kg} / \mathrm{cm}^{2}
\end{aligned}
$$

2) Kapasitas dukung ujung persatuan luas (qb):

$$
\begin{aligned}
& \mathrm{q}_{\mathrm{b}}=\frac{\mathrm{q}_{\mathrm{ca}}(\text { base })}{\mathrm{F}_{\mathrm{b}}}\left(\text { Nilai } F_{b} \text { dari tabel untuk beton precast }=1,75\right) \\
& \mathrm{q}_{\mathrm{b}}=\frac{137}{1,75}=78,28 \mathrm{~kg} / \mathrm{cm}^{2}
\end{aligned}
$$

3) Kapasitas dukung ujung tiang pancang $\left(Q_{b}\right)$ :

$\mathrm{Q}_{\mathrm{b}}=\mathrm{q}_{\mathrm{b}} \times \mathrm{A}_{\mathrm{b}}$

$\mathrm{Q}_{\mathrm{b}}=78,28 \times 1963,49=153701,99 \mathrm{~kg}=153,70$ ton

b. Perhitungan Kapasitas Dukung Kulit $\left(\mathrm{Q}_{\mathrm{c}}\right)$ :

1) Kapasitas dukung kulit persatuan luas (f):

$$
\begin{aligned}
& \mathrm{f}=\mathrm{q}_{\mathrm{c}} \text { (side) } \frac{\mathrm{as}}{\mathrm{Fs}} \text { (nilai as dan } F s \text { dari tabel) } \\
& \mathrm{f}=55,56 \times \frac{0,014}{3,5}=0,222 \mathrm{~kg} / \mathrm{cm}^{2}
\end{aligned}
$$

2) Kapasitas dukung kulit tiang pancang (Qs) :

$\mathrm{Q}_{\mathrm{S}}=\mathrm{f} \times \mathrm{A}_{\mathrm{s}} \times$ kedalaman $(\mathrm{cm})$

$\mathrm{Q}_{\mathrm{S}}=0,222 \times 157,079 \times 2200=76717,38 \mathrm{~kg}=76,72$ ton

Jadi, kapasitas dukung ultimit tiang pancang adalah :

$$
\begin{aligned}
& Q_{u}=Q_{b}+Q_{s} \\
& Q_{u}=153,70+76,72=230,42 \text { ton }
\end{aligned}
$$

3) Kapasitas ijin tiang (Qa) adalah :

$$
\mathrm{Q}_{\mathrm{a}}=\frac{\mathrm{Q}_{\mathrm{u}}}{\mathrm{SF}}=\frac{230,42}{2,5}=92,17 \text { ton }
$$

Jadi, kapasitas daya dukung tiang tunggal dengan metode Aoki dan De Alencar adalah sebesar 230,43 ton, dan kapasitas ijin tiang adalah sebesar 92,17 ton > 68,468 ton (aman).

2. Metode Langsung

Dihitung untuk kedalaman tiang pancang 22 meter Dengan data sondir sebagai berikut: 
Tabel 1. Data Sondir Titik STA. 10+700

\begin{tabular}{|c|c|c|}
\hline Kedalaman $(\mathrm{m})$ & Perlawanan Konus $\left(\mathrm{kg} / \mathrm{cm}^{2}\right)$ & $\mathrm{JHL}\left(\mathrm{kg} / \mathrm{cm}^{2}\right)$ \\
\hline 18.00 & 14 & 2166.486 \\
\hline 18.20 & 27 & 2220.649 \\
\hline 18.40 & 49 & 2328.973 \\
\hline 18.60 & 57 & 2383.135 \\
\hline 18.80 & 65 & 2437.297 \\
\hline 19.00 & 81 & 2599.784 \\
\hline 19.20 & 95 & 2708.108 \\
\hline 19.40 & 111 & 2870.595 \\
\hline 19.60 & 122 & 2978.919 \\
\hline 19.80 & 135 & 3033.081 \\
\hline 20,00 & 135 & 3195.568 \\
\hline 20,20 & 135 & 3249.73 \\
\hline 20,40 & 138 & 3412.216 \\
\hline 20,60 & 141 & 3574.703 \\
\hline 20,80 & 149 & 3683.027 \\
\hline 21,00 & 157 & 3683.027 \\
\hline 21,20 & 159 & 3628.865 \\
\hline 21,40 & 138 & 4062.162 \\
\hline 21,60 & 141 & 4224.649 \\
\hline 21,80 & 130 & 4332.973 \\
\hline 22,00 & 127 & 4441.297 \\
\hline
\end{tabular}

Sumber:Data Sekunder P2JN Kalteng, (2020)

1) qc1 adalah rata-rata qc $8 \mathrm{D}$ diatas tiang yang ditinjau, qc1 kedalaman 22 meter.

$$
\begin{aligned}
\mathrm{qc} 1 & =\frac{14+27+49+57+65+81+95+111+122+135+135+135+}{21} \\
& =109,652 \mathrm{~kg} / \mathrm{cm}^{2}
\end{aligned}
$$

2) qc2 adalah rata-rata qc 4D bawah tiang yang ditinjau, qc2 kedalaman 22 meter

$\mathrm{qc} 2=\frac{127+127+127+127+127+127+127+127+127+127+127+127}{12}=127 \mathrm{~kg} / \mathrm{cm}^{2}$

3) Tahanan ultimit ujung tiang (qp) :

$\mathrm{qp}=(\mathrm{qc} 1+\mathrm{qc} 2) / 2$

$\mathrm{qp}=(109,625+127) / 2=118,3262 \mathrm{~kg} / \mathrm{cm}^{2}$

4) Kapasitas daya dukung tiang pancang tunggal (Qult) :

Qult $\quad=\mathrm{qp} \times \mathrm{Ab}+\mathrm{JHL} \times \mathrm{As}$

Qult $=118,3262 \times 1963,495+4441,297 \times 157,079$

$=929967,39 \mathrm{~kg}$

$=929,967$ ton

5) Kapasitas ijin tiang $\left(\mathrm{Q}_{\mathrm{ijin}}\right)$ adalah :

Qijin $=(\mathrm{qp} \times \mathrm{Ab}) / 3+(\mathrm{JHL} \times \mathrm{K}) / 5$

$=(136,85 \times 1963,495) / 3+(4441.297 \times 157,079) / 5$

$=216971,199 \mathrm{~kg}$

$=216,971$ ton 
Jadi, kapasitas daya dukung tiang tunggal dengan metode Langsung adalah sebesar 929,967 ton, dan kapasitas ijin tiang adalah sebesar 216,971 ton > 68,468 ton (aman)

3. Metode Philipponnat

Dihitung untuk kedalaman tiang pancang 22 meter dengan data sondir sebagai berikut :

Tabel 2. Data Sondir Titik STA. $10+700$

\begin{tabular}{|c|c|c|}
\hline Kedalaman $(\mathrm{m})$ & Perlawanan Konus $\left(\mathrm{kg} / \mathrm{cm}^{2}\right)$ & JHL $\left(\mathrm{kg} / \mathrm{cm}^{2}\right)$ \\
\hline 20,40 & 138 & 3412.216 \\
\hline 20,60 & 141 & 3574.703 \\
\hline 20,80 & 149 & 3683.027 \\
\hline 21,00 & 157 & 3683.027 \\
\hline 21,20 & 159 & 3628.865 \\
\hline 21,40 & 138 & 4062.162 \\
\hline 21,60 & 141 & 4224.649 \\
\hline 21,80 & 130 & 4332.973 \\
\hline 22,00 & 127 & 4441.297 \\
\hline
\end{tabular}

Sumber:Data Sekunder P2JN Kalteng, (2020)

1) Perhitungan kapasitas dukung ujung tiang $\left(\mathrm{q}_{\mathrm{p}}\right)$ :

$$
\begin{aligned}
& \mathrm{q}_{\mathrm{p}}=\alpha \mathrm{p} \times \underline{\mathrm{R}}_{\mathrm{p}} \text {, dengan } \underline{\mathrm{R}}_{\mathrm{p}}=\frac{1}{6 s} \int_{Z p-3 p}^{Z p+3 p} Z R p(z) d z \\
& \begin{aligned}
& 127+130+141+138+159+157+ \\
& \underline{\mathrm{R}}_{\mathrm{p}}=\frac{1}{6 \times 50} \int_{2200-3 \times 50}^{2200+3 \times 50} \frac{149+141+127+127+127+127+127+127+127}{15}(z) d z \\
&=135,4 \mathrm{~kg} / \mathrm{cm}^{2}
\end{aligned} \\
& \mathrm{q}_{\mathrm{p}}=0,4 \times 135,4=54,16 \mathrm{~kg} / \mathrm{cm}^{2}
\end{aligned}
$$

2) Kapasitas dukung ujung tiang pancang $\left(\mathrm{Q}_{\mathrm{p}}\right)$ :

$$
\mathrm{Q}_{\mathrm{p}}=\frac{A x q p}{3}=\frac{1963,495 \times 54,16}{3}=35447,62 \mathrm{~kg}=35,448 \text { ton }
$$

3) Perhitungan kapasitas dukung kulit tiang (Qs):

$$
\begin{aligned}
& \mathrm{Q}_{\mathrm{s}}=\frac{P}{3} x J H P \\
& \mathrm{Q}_{\mathrm{s}}=\frac{157,079}{3} x 4441.297=232544,831 \mathrm{~kg}=232,545 \text { ton }
\end{aligned}
$$

4) Kapasitas dukung ultimit tiang pancang (Qult) :

$$
\begin{aligned}
& \text { Qult }=35,448+232,545=268,033 \text { ton } \\
& \text { Qijin }=268,033 / 3=89,344 \text { ton }
\end{aligned}
$$

Jadi, kapasitas daya dukung tiang tunggal dengan metode Philipponnat adalah sebesar 268,033 ton, dan kapasitas ijin tiang adalah sebesar 89,344 ton $>68,468$ ton (aman). 


\section{Perhitungan Kapasitas Daya Dukung Kelompok Tiang Berdasarkan Effisiensi}

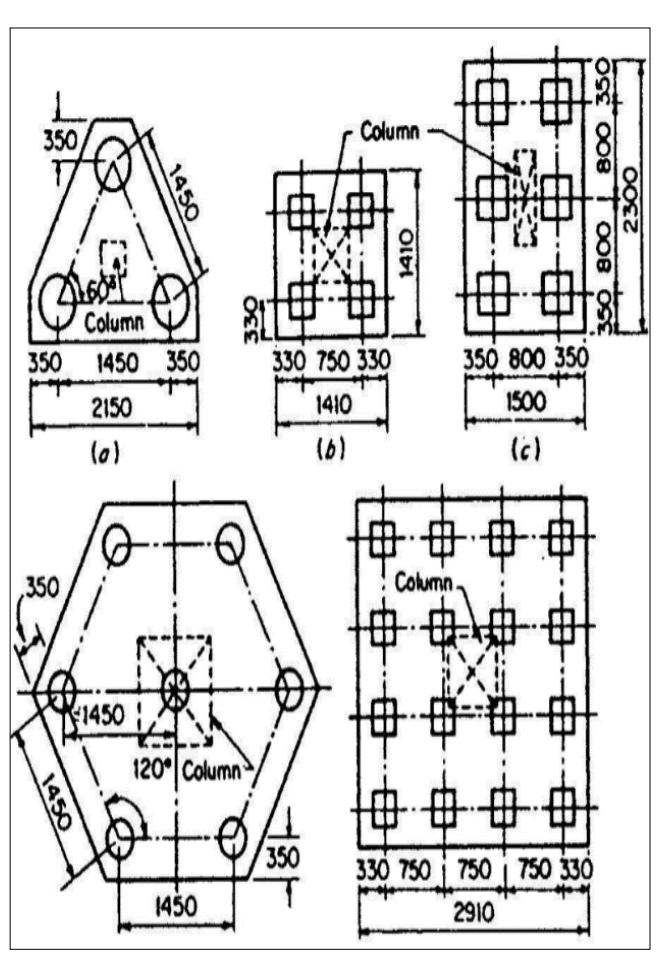

(a)

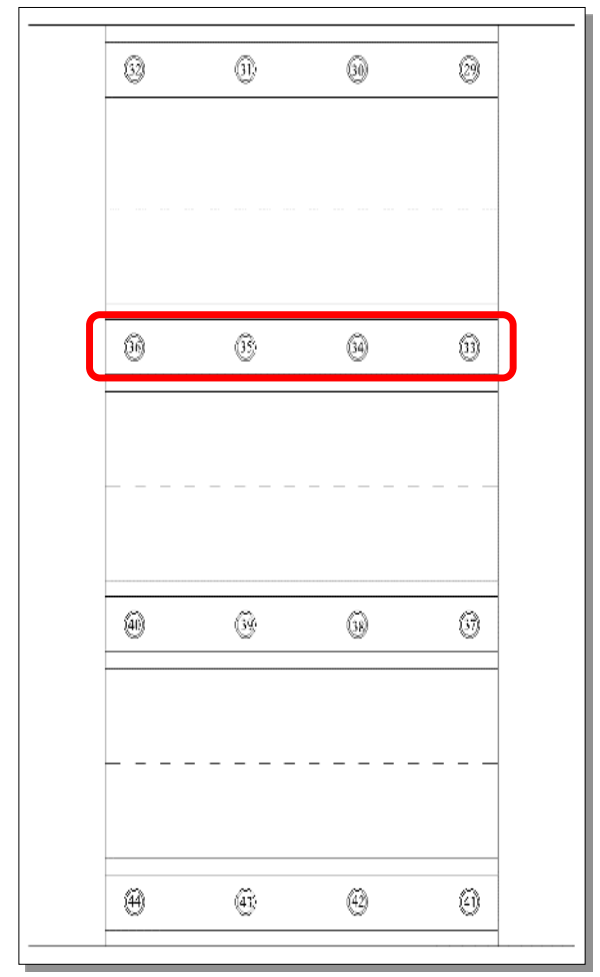

(b)

Gambar 2. Konfigurasi Kelompok Tiang

Sumber: Bowles, Joseph E. 1997

Pada gambar 2(a) merupakan gambar konfigurasi kelompok tiang tipikal yang dipakai sesuai konsdisi denah rencana. gambar 2(b) merupakan kelompok tiang tipikal yang di pakai.

Digunakan metode Converse-Labare untuk menghitung effisiensi tiang sebagai berikut:

$$
\begin{aligned}
& \mathrm{Eg}=1-\Theta \frac{\left(\mathrm{n}^{\prime}-1\right) \times \mathrm{m}+(\mathrm{m}-1) \times \mathrm{n}^{\prime}}{90 \times \mathrm{m} \times \mathrm{n}} \\
& \Theta \quad=\operatorname{Arctg} \mathrm{D} / \mathrm{S}=\operatorname{Arctg}(50 / 270)=10,492^{\circ} \\
& \mathrm{n}^{\prime}=4 \\
& \mathrm{~m}=1 \\
& \mathrm{Eg}=1-10,492 \frac{(4-1) \times \mathrm{m}+(\mathrm{m}-1) \times 4}{90 \times \mathrm{m} \times 4}=0,913
\end{aligned}
$$

1) Kapasitas dukung kelompok ijin tiang (Qg):

$\mathrm{Q}_{\mathrm{g}}=\mathrm{E}_{\mathrm{g}} \times \mathrm{n} \times \mathrm{Q}_{\mathrm{a}}$

Diambil contoh untuk metode Meyerhof

$\mathrm{Q}_{\mathrm{g}}=0,913 \times 4 \times 91,01=332,369$ ton 
Tabel 3. Rekapitulasi Daya Dukung Tiang Pancang Kelompok

\begin{tabular}{|c|l|c|}
\hline No. & \multicolumn{1}{|c|}{ Nama Metode } & $\begin{array}{c}\text { Kapasitas dukung kelompok } \\
\text { ijin tiang }\left(\mathrm{Q}_{\mathrm{g}}\right)\end{array}$ \\
\hline 1 & Meyerhof & 332,369 ton \\
\hline 2 & L. Decourt & 146,602 ton \\
\hline 3 & Aoki dan De Alencar & 336,605 ton \\
\hline 4 & Langsung & 792,378 ton \\
\hline 5 & Philipponnat & 326,284 ton \\
\hline
\end{tabular}

Jadi, kapasitas dukung kelompok ijin tiang pada STA 10+700 dengan metode Meyerhof 332,369 ton > 68,468 ton (aman). Dengan metode L. Decourt 146,602 ton > 68,468 ton (aman). Dengan metode Aoki dan De Alencar 336,605 ton > 68,468 ton (aman). Dengan metode Langsung 792,378 ton $>68,468$ ton (aman). Dengan metode Philipponnat 326,284 ton > 68,468 ton (aman).

\section{Penurunan Tiang Pancang Tunggal}

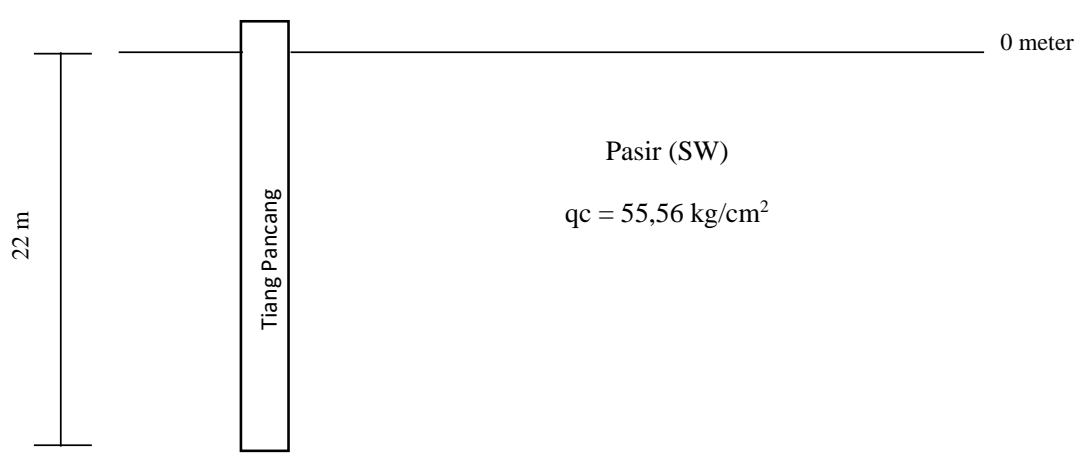

Gambar 3. Nilai qca Side

a. Modulus elastisitas tanah disekitar tiang (Es):

$$
\begin{aligned}
\mathrm{E}_{\mathrm{s}} & =3 \times \mathrm{qc} \\
& =3 \times 55,56 \mathrm{~kg} / \mathrm{cm}^{2} \\
& =166,68 \mathrm{~kg} / \mathrm{cm}^{2} \\
& =16,668 \mathrm{Mpa}
\end{aligned}
$$

b. Modulus elastis di dasar tiang (Eb):

$$
\begin{aligned}
\mathrm{E}_{\mathrm{b}} & =10 \times \mathrm{E}_{\mathrm{s}} \\
& =3 \times 16,668 \mathrm{Mpa} \\
& =166,68 \mathrm{Mpa}
\end{aligned}
$$

c. Menetukan modulus elastisitas dari bahan tiang :

Dengan mutu beton K- 300 maka fc' $=300 \mathrm{~kg} / \mathrm{cm}^{2}=30 \mathrm{Mpa}$

$$
\begin{aligned}
\mathrm{E}_{\mathrm{p}} & =4700 \times \sqrt{f c^{\prime}} \\
& =4700 \times \sqrt{30} \\
& =25742,96 \mathrm{Mpa}
\end{aligned}
$$

$$
\mathrm{Ra}=\frac{A_{P}}{\text { luas }}=\frac{1963,49}{1963,49}=1
$$


d. Menentuan faktor kekakuan tiang :

$$
\mathrm{K}=\frac{E_{p} \times R_{a}}{E_{s}}=\frac{25742,96 \times 1}{16,668}=1544,454
$$

$\mathrm{db}$ adalah diameter tiang pancang ujung, $\mathrm{d}$ adalah diameter tiang pancang atas dan $\mathrm{L}$ adalah kedalaman tiang pancang dari muka tanah sampai tanah keras. Untuk $\mathrm{db} / \mathrm{d}$ $=50 / 50=1$, sisi ujung dan atas sama. Untuk L/d $=2200 / 50=44$

e. Dari masing-masing grafik didapat :

$$
\begin{aligned}
& \mathrm{I}_{0}=0,05(\text { untuk } \mathrm{L} / \mathrm{d}=44 \text { dan } \mathrm{db} / \mathrm{d}=1) \\
& \mathrm{R}_{\mathrm{k}}=1,09(\text { untuk } \mathrm{L} / \mathrm{d}=44 \text { dan } \mathrm{K}=1544,454) \\
& \mathrm{R}_{\mu}=0,909(\text { untuk } \mu \mathrm{s}=0,25 \text { dan } \mathrm{K}=1544,454) \\
& \mathrm{R}_{\mathrm{h}}=0,40(\text { untuk } \mathrm{L} / \mathrm{d}=44 \text { dan } \mathrm{h} / \mathrm{L}=1) \\
& \mathrm{R}_{\mathrm{b}}=0,39(\text { untuk } \mathrm{L} / \mathrm{d}=44 \text { dan } \mathrm{Eb} / \mathrm{Es}=10) \\
& \mathrm{K}=1544,454
\end{aligned}
$$

\begin{tabular}{|c|c|c|}
\hline No. & Bentuk Penurunan & Penurunan Tiang (S) \\
\hline 1. & Untuk tiang apung atau friksi & $3,7 \mathrm{~mm}$ \\
\hline 2. & Untuk tiang dukung ujung & $3,6 \mathrm{~mm}$ \\
\hline & Perkiraan Penurunan Total & $7,3 \mathrm{~mm}$ \\
\hline
\end{tabular}

1. Tiang apung friksi :

$$
\begin{aligned}
\mathrm{I} & =\mathrm{I}_{0} \times \mathrm{R}_{\mathrm{k}} \times \mathrm{R}_{\mathrm{h}} \times \mathrm{R}_{\mu}=0,05 \times 1,09 \times 0,40 \times 0,909 \\
& =0,198 \\
\mathrm{~S} & =\frac{\mathrm{Q} \mathrm{I}}{\mathrm{E}_{\mathrm{S}} \times \mathrm{D}}=\frac{15790 \times 0,198}{166,68 \times 50}=0,37 \mathrm{~cm}=3,7 \mathrm{~mm}
\end{aligned}
$$

Tiang dukung ujung :

$$
\begin{aligned}
\mathrm{I} & =\mathrm{I}_{0} \times \mathrm{R}_{\mathrm{k}} \times \mathrm{R}_{\mathrm{h}} \times \mathrm{R}_{\mu}=0,05 \times 1,09 \times 0,39 \times 0,909 \\
& =0,193 \\
\mathrm{~S} & =\frac{\mathrm{QxI}}{\mathrm{E}_{\mathrm{s}} \times \mathrm{D}}=\frac{15790 \times 0,193}{166,68 \times 50}=0,36 \mathrm{~cm}=3,6 \mathrm{~mm}
\end{aligned}
$$

2. Hasil penurunan tiang total :

Tabel 4. Rekapitulasi Penurunan Tiang Pancang Titik 35

\section{Penurunan yang di Ijinkan}

Penurunan yang diijinkan memiliki rumus $10 \%$ dari sisi tiang pancang. Maka penurunan yang diijinkan adalah sebagai berikut :

$$
\mathrm{S}_{\mathrm{ijin}}=10 \% .500 \mathrm{~mm}=50 \mathrm{~mm}=5 \mathrm{~cm}
$$

Dengan syarat Penurunan tiang tunggal < penurunan ijin.

Jadi, penurunan tiang pancang tunggal pada STA 10+700 7,3 $\mathrm{mm}<50 \mathrm{~mm}$ (aman).

\section{Penurunan Kelompok Tiang}

Penurunan kelompok tiang memiliki rumus sebagai berikut :

$$
\mathrm{S}_{\mathrm{g}}=\frac{\mathrm{q} \times \mathrm{B}_{\mathrm{g}} \times \mathrm{I}}{2 \times \mathrm{qc}}
$$


1. Tiang pancang titik 35 :

$$
\begin{aligned}
& q=\frac{Q}{L_{g} \times B_{g}}=\frac{152133}{270 \times 270}=2,08 \mathrm{Kg} / \mathrm{cm}^{2} \\
& I=1-\frac{L}{8 \times B_{g}} \geq 0,5 \quad I=1-\frac{950}{8 \times 270}=0,43<0,5
\end{aligned}
$$

2. Penurunan tiang pancang kelompok titik 35 sebagai berikut:

$$
\mathrm{S}_{\mathrm{g}}=\frac{\mathrm{q} \times \mathrm{B}_{\mathrm{g}} \times \mathrm{I}}{2 \times \mathrm{qc}}=\frac{2,08 \times 270 \times 0,43}{2 \times 248,6484}=0,48 \mathrm{~cm}=4,8 \mathrm{~mm}
$$

Penurunan tiang pancang kelompok pada STA $10+700$ adalah 4,8 mm $<50 \mathrm{~mm}$ berati aman terhadap penurunan dan penurunan tiang pancang kelompok yang terjadi.

\section{PENUTUP}

\section{Kesimpulan}

Dari analisis pembahasan yang telah dibuat maka dapat dibuat kesimpulan sebagai berikut :

1. Kapasitas daya dukung pile slab yang terjadi pada jembatan berdasarkan uji SPT dengan metode Meyerhof memiliki kapasitas dukung ijin ultimit sebesar 91,01 ton (aman), dengan metode L Decourt memiliki kapasitas dukung ijin ultimit sebesar 40,143 ton (tidak aman). Kapasitas daya dukung pile slab yang terjadi pada jembatan berdasarkan uji CPT dengan metode Aoki dan De Alencar memiliki kapasitas dukung ijin ultimit sebesar 92,17 ton (aman), dengan metode Langsung memiliki kapasitas dukung ijin ultimit sebesar 216,971 ton (aman), dengan metode Philipponnat memiliki kapasitas dukung ijin ultimit sebesar 89,344 ton (aman).

2. Penurunan yang terjadi pada pile slab di jalan Bukit Rawi adalah sebesar 7,3 mm $<50 \mathrm{~mm}$ berarti aman.

\section{Saran}

1. Penyelidikan tanah harus dilakukan secara teliti, agar diperoleh data yang sesuai dengan kondisi tanah yang sebenarnya.

2. Perhitungan kapasitas daya dukung pada penelitian ini terbatas, hanya menggunakan metode Mayerhof, L Decourt, Aoki dan De Alencar, Langsung, Philipponnat. Apabila diteli lebih lanjut dapat menggunakan metode lainnya.

3. Perhitungan daya dukung dapat dilakukan menggunakan program- program software sehingga didapatkan hasil yang lebih akurat. 


\section{DAFTAR PUSTAKA}

1. Bowles, Joseph E. 1997. Analisis dan Desain Fondasi Jilid 1 Edisi 4. Jakarta: Erlangga Tabel System uscs

2. Cahyono, Arif Budi. 2011. Studi Pelaksanaan Pekerjaan Tiang Pancang Piled Slab (Fly Over) Jembatan Martadipura Tenggarong Kalimantan Timur. Skripsi. Universitas Negeri Malang : Malang.

3. Hardiyatmo, C. H. 2002. Mekanika Tanah II. Yogyakarta: Gajah Mada University Press.

4. SNI 1725:2016. 2016. Pembebanan Untuk Jembatan. Badan Standarisasi Nasional. Bandung.

5. SNI 2847-2013. 2013. Persyaratan Beton Struktural Untuk Bangunan Gedung. Badan Standarisasi Nasional. Bandung.

6. SNI T-02-2005. 2005. Standar Pembebanan Untuk Jembatan. Badan Standarisasi Nasional. Bandung.

7. Wahyudi, Herman. 1999. Daya Dukung Fondasi Dalam. Surabaya : Jurusan Teknik Sipil - FTSP ITS

8. Wijaya, Septian Tesa. 2018. Analisis Perbandingan Daya Dukung Fondasi Telapak Serta Perancangan Fondasi Telapak Pada Tribun Stadion (Studi Kasus Stadion Hinang Golloa, Kecamatan. 